\title{
O Ensino Médio na Realidade Brasileira: As Possiveis Saídas e os Impasses na Execução de seu Estudo
}

Pesquisadora: Ednar Carvalho Cavalcanti

Instituição: Universidade Federal de Pernambuco (UFPE)

Fonte Financiadora: Instituto Nacional de Estudos e Pesquisas Educacionais (INEP)

\section{Do Projeto}

Trata-se de projeto nacional SUDENE, cujos resultados estão desenvolvido por nove estados da condensados no livro O Ensino Médio Federação, financiado pelo INEP, no Brasil: da ruptura do privilégio à FINEP e, em alguns casos, pelo CNPq, conquista do direito (Mafra e Cavalcanti, por Secretarias da Educação e pela Brasília: INEP, 1992,136p.). 
OBJETIVO

Identificar os diferentes tipos de ensino no nivel de $2^{\circ}$ grau e propiciar sua análise, referenciada à questão de sua democratização, pretendendo oferecer uma contribuição significativa, não apenas para a compreensão da realidade escolar mas para a busca de alternativas concretas à prática pedagógica existente.

\section{REFERENCIAIS TEÓRICOS}

As questões da desigualdade social e da heterogeneidade entre escolas têm como pano de fundo as condições sociais inerentes à sociedade brasileira. No substrato desses problemas está a questão da democratização da educação, no tocante ao acesso, à permanência e à conclusão do curso, todos esses pontos permeados por fatores intra e extra-escolares.

O estudo das desigualdades sociais pode ser completado por informações sobre o que efetivamente ocorre dentro da escola. Apesar de nem sempre ser possível comparar resultados escolares, em razão da grande heterogeneidade do sistema de ensino e das condições em que operam as escolas, o exame de alguns dados enriquecem a análise desse problema. Estas informações pouco significam isoladamente, mas podem revelar a real dimensão da desigualdade, se for verificada a forma eoo estão associados entre si e com os dados referentes ao perfil do alunado.

$\mathrm{O}$ acesso de todos ao ensino de $2^{\circ}$ grau é uma das condições necessárias para a democratização da educação, embora não seja suficiente, pois permanecem ainda questões fundamentais acerca da qualidade e da natureza do ensino diferencialmente proporcionado. A questão da heterogeneidade entre as escolas, em termos da experiência pedagógica e das condições de sua realização, aponta para problemas históricos permanentes na educação brasileira, que não se resolveram, apesar da tentativa das diversas reformas educacionais, tornando-se, talvez, até mais complexos pelo acúmulo de contradições de diversos matizes.

A problemática da diversidade entre as escolas de $2^{\circ}$ grau transcende a diferenciação decorrente da dependência administrativa 
pública ou privada, por existirem dentro de cada um desses segmentos variações de qualidade que fazem, em determinado momento, aproximarem-se certas escolas públicas de certas escolas privadas.

Nessa perspectiva, a análise do problemas deve ser referenciada a questões mais amplas, situando-o dentro da questão da política educacional. Isso pressupõe estudar o significado e a direção da expansão do sistema de ensino c o papel do Estado nesse processo, considerando duas tendências importantes que têm sido verificadas: de um lado, a incorporação crescente de alunos de origens sociais heterogêneas c, de outro, o processo também crescente de divisão e especialização do trabalho.

A participação precoce dos jovens no mundo da produção passa a impor novas formas de articulação entre o ensino e esse mundo, sendo essencial que a escola assuma isto.

METODOLOGIA

Amostra - Critérios Gerais

Todas as regiões do País estão representadas por um ou mais estados (Paraná, Santa Catarina, São Paulo, Minas Gerais, Goiás, Pernambuco, Rio Grande do Norte, Maranhão, Pará).

- Critérios para o primeiro nivel de investigação

Universo das escolas de todos os municípios da cada estado, procurando caracterizar o ensino, num continuum histórico, a partir de Lei 5.692/71, cm estudo com dados secundários.

- Critérios para o segundo nível de investigação

- Doze por cento das escolas públicas e privadas, diurnas e noturnas; nelas, $5 \%$ dos alunos de cada turma c pelo menos dois professores por área de conhecimento e por turno, para conhecer a dinâmica interna da escola, em estudo com dados primários.

Da análise interativa dos dados

Tendo como pano de fundo a questão da democratização, este estudo sobre o então ensino de $2^{\circ}$ grau considerou fatores intra e extra-escolares como intervenientes na heterogeneidade entre as escolas e entre diferentes turnos de um mesmo estabelecimento. 
Circunscreveram-se na análise do processo de democratização dados referentes à ampliação do acesso e ao perfil do aluno e do professor componentes desse grau de ensino. Foram considerados, ainda, os fenômenos de evasão e de reprovação, bem como o tipo e o nível de ensino veiculado - indicadores internos da qualidade do que se produz e transmite nessa escola.

$\mathrm{Na}$ perspectiva de que os problemas não são gerados apenas na escola nem nela se encerram, foram enfocados dados que demonstram como o modelo econômico que vem sendo adotado no País, por desconsiderar o social, interpõe-se entre a luta e a conquista de escolarização pelos estratos mais pobres da população e sua formação qualificada "para a vida".

A análise do movimento escolar apontou um incremento no atendimento da demanda, mas insignificante, na medida em que aproximadamente $85 \%$ da população em idade de fregüentar o ensino de $2^{\circ}$ grau encontrava-se fora dele, sem contar que muitos dos incorporados ao sistema tinham idade acima do limite esperado, que aproximadamente a metade dos atendidos se evadem e que um percentual igualmente significativo é reprovado.

Essa evidência oferece, para a análise, a outra face da democratização ensino - o tipo e o nível dos conhecimentos veiculados em seu processo.

Depreendeu-se da análise dos resultados, a desqualificação do ensino do $2^{\circ}$ grau, ensejando, inclusive, a quebra da percepção dicotômica entre ensino público/ensino privado.

O estudo apontou que tanto alunos quanto professores são oriundos dos segmentos mais pobres da população, ambas as categorias enfrentando uma extensa jornada de trabalho, acossadas pela necessidade de sobrevivência. Os primeiros demonstraram ter clareza de que a escola não os está preparando "nem para o vestibular nem para a vida" e denunciaram o despreparo dos docentes do ponto de vista dos conteúdos, da metodologia e das relações; apontaram as condições de ensino comprometidas pela baixa remuneração recebida pelos professores, pela precariedade e/ou inexistência de 
recursos didáticos. Os professores, na maioria, referem-se sempre à desqualificação do ensino como fenômeno fruto de múltiplas razões sociais, políticas e econômicas que se refletem na escola e nos alunos, mas se descomprometem, não incluindo sua categoria como coresponsável por essa deterioração.

Ficou evidenciada a ausência de uma política definidora da qualidade necessária à formação do jovem trabalhador. Na escola isto se expressa numa organização curricular (horário, atividades, disciplinas e seus conteúdos programáticos, metodologia de ensino, sistema de avaliação, relacionamento professor-aluno) que ignora as condições de vida do jovem que vem assomando, sobretudo, à escola da rede pública.

Ficou enfatizada, também, a inexistência de uma política de capacitação do pessoal docente, o que permite seu caráter ocasional e da iniciativa de alguns.

\section{Das saídas para um ensino qualificado}

. Definição de uma política salarial e de capacitação permanente do docente.
. Estabelecimento da identidade do ensino médio.

- Busca de mecanismos que levem a uma maior integração, na escola, entre o pessoal docente, discente, administrativo e técnico.

- Descentralização das decisões, com maior autonomia administrativa e pedagógica em relação às Secretarias da Educação.

- Participação dos alunos nas instâncias decisorias.

. Resgate da autonomia do professor.

- Articulação orgânica entre a escola e o mundo do trabalho.

- Ampliação e estabelecimento de uma nova ordem nas relações entre escola e sociedade.

\section{Dos impasses, desafios e conquistas}

IMPASSES

- Liberação atrasada de recursos e sem atualização.

- Descontinuidade de cumprimento do cronograma dos encontros entre as equipes estaduais que realizavam o projeto.

- Financiamento do projeto por diferentes órgãos, cada um com prazos distintos. 
- Mudanças frequientes nos dados tibilização de suas ações e dados. pedidos ao sistema de ensino pelos . Superação e luta contra a mudança formulários do MEC. de filosofia e de política a cada gestão do rNEP, durante a evolução DESAFIOS E CONQUISTAS da pesquisa.

. Expansão do projeto ao interior . Constituição de equipes inter- de alguns estados. disciplinares, algumas das quais. Incorporação de graduandos e estão hoje consolidadas, realizando recém-graduados nas atividades de novos projetos. pesquisa na área educacional, alguns - Interação com equipes geo- dos quais ingressaram em cursos de graficamente separadas e compa- mestrado. 